\title{
Survey of the Middle Struma Complex Morphostructural Passage (South-West Bulgaria)
}

\author{
Tzanko Tzankov ${ }^{1}$, Svetla Stankova $^{2}$, Rosen Iliev $^{1, *}$, Ilia Mitkov $^{1}$ \\ ${ }^{1}$ Faculty of Mathematics and Natural Sciences, South-West University "NeofitRilski", Bulgaria \\ ${ }^{2}$ Faculty of Natural Sciences, "Konstantin Preslavsky" University, Bulgaria
}

Copyright $\bigcirc 2017$ by authors, all rights reserved. Authors agree that this article remains permanently open access under the terms of the Creative Commons Attribution License 4.0 International License

\begin{abstract}
The Middle Struma complex

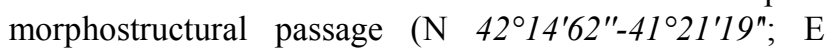
$24^{\circ} 10^{\prime} 21^{\prime \prime}-23^{\circ} 20^{\prime} 21^{\prime \prime}$ ) is a negative landform located in South-West Bulgaria. Represents a negative regional morphounit composed of linear orderly (from north to the south) Dupnitsa morphostructural threshold, Dzherman morphostructural passage, Slatino morphostructural threshold, Mursalevo morphostructural passage, Kocherinovo morphostructural threshold, Riltsi kettle morphostructure, Byalo Pole morphostructural threshold, Blagoevgrad kettle morphostructure, Zheleznitsa morphostructural gorge, Simitli kettle morphostructure, Kresna morphostructural gorge, Sandanski morphostructural passage, Damyanitsa morphostructural threshold, Petrich kettle morphostructure and Rupel morphostructural gorge. The mentioned regional complex morphounits are limited by Bregalnitsa morphostructural zone to the west and the Rila-Pirin morphostrutural range to the east. The Middle Struma complex morphostructural passage is the relict from the post Early Pleistocene orthoplain in the eastern part of the Balkan Peninsula. The internal morphostructures of that orthoplain fragment were formed in the same time with the building of the dome-like morphostructures of the Bregalnitsa morphostructural zone and the Rila-Pirin morphostrutural range.
\end{abstract}

Keywords Orthoplain, Morphostructural Passage, Gorge, Threshold, Kettle, Morphostructures, Bulgaria

\section{Introduction}

The article considers the questions about the geodynamic precondition for the origin, evolution and internal pattern of the Middle Struma complex morphostructural passage in South-West Bulgaria. The differentiation and definition of those regional morphounit is connected to the mobile (Plate tectonics) interpretation of the Neogene-Quaternary morphotectonic evolution of the eastern part of Balkan Peninsula. This modern geodynamic concept is completely contradicted with the former geosynclinals geotectonic hypothesis from the last decades of the twenty century. Most previous studies on structural features and geodynamic evolution of the studied area are based on the already lost geosynclinal hypothesis (Bakalov, [1]; Kojumdgieva et al., [2], [3]; Nedjalkov et al., [4], [5]; Zagorchev, [6]).

The first fifteen years of the century were connected to the gradual explanation and utilisation of the morphostructural terminology and the regional characteristics of the Middle Struma complex morphostructural passage (Tzankovet al., [7], Tzankov, [8]). They built up a complete concept for the temporal, geodynamic and morphostructural essence of those compound regional negative morphounit. The article main goal is to present contemporary authors views for the geodynamic evolution of the study area based on various geological-tectonic, geomorphological and seismic surveys.

\section{Study Area}

The Middle Struma complex morphostructural passage (MSCMSP) (N 42 $14^{\prime} 62^{\prime \prime}-41^{\circ} 21^{\prime} 19^{\prime \prime}$; E $24^{\circ} 10^{\prime} 21^{\prime \prime}-23^{\circ} 20^{\prime} 21^{\prime \prime}$ ) is disposed on the areas of the Dzherman River Valley (between the towns of Dupnitsa and Boboshevo) and Middle Struma River Valley (between the town of Boboshevo and the Rupel gorge) in South-West Bulgaria (Figure 1). The passage is limited by the eastern slopes of Belasitsa, Ograzhden, Maleshevo and Vlahina mountains to the west and by west slopes of Rila, Pirin and Sengelitsa (in Greece) mountains to the east (Figure 1). All those area belong to the Middle Struma catchments basin. 


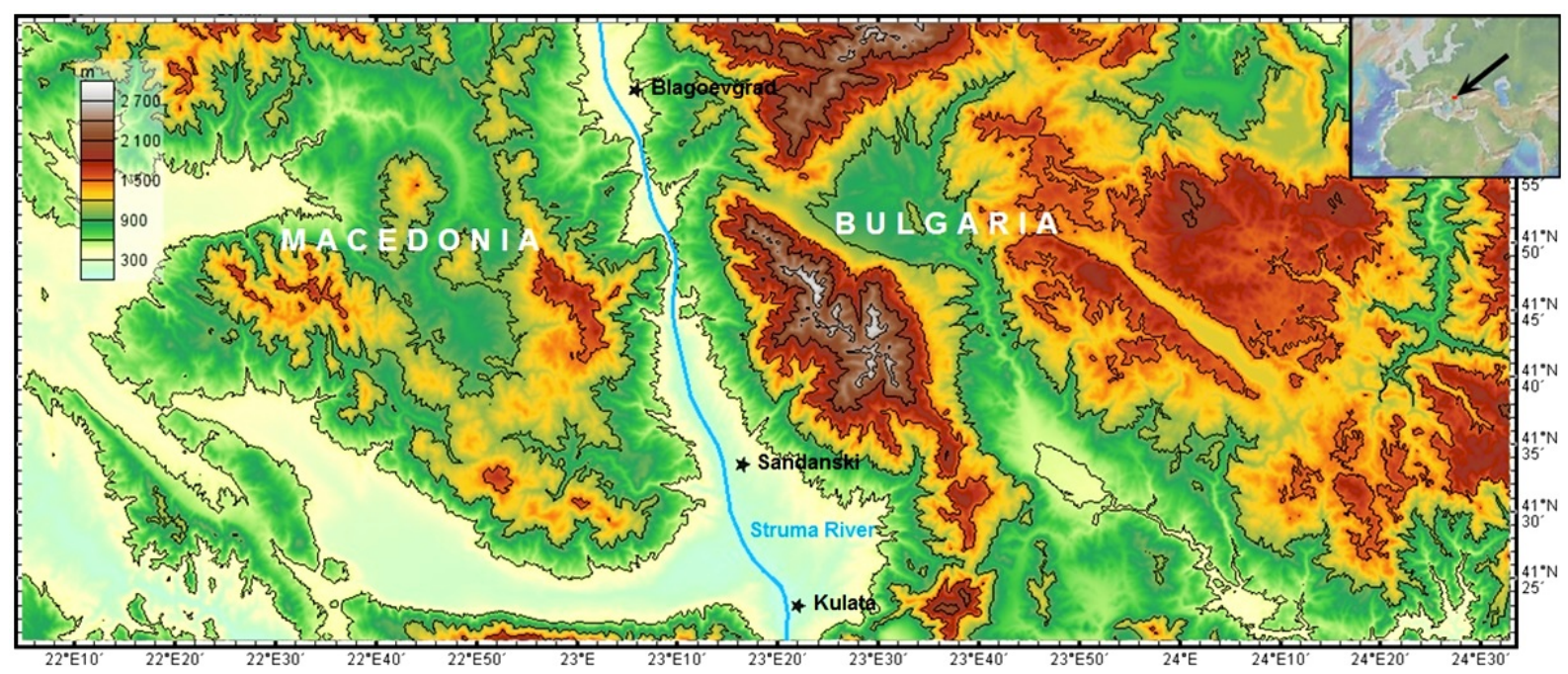

Figure 1. Survey maps of the regional disposition of the Middle Struma complex morphostructural passage (Mapping tool: GeoMapApp-http://www.geomapapp.org)

\section{Methodology}

The proposed regional morphological study is based on generally accepted contemporary and already well-grounded scientific mobilistic Plate tectonics presents for the construction of the upper parts of the Earth's crust from different by size and number oceanic and continental plates (Tzankov, [9]). They are found in complex temporal and spatial relationships by the action of endogenous geodynamic processes.

The complex morphostructural passage is a secondary negative regional morphounit in the scope of the positive mountain morphounits. It is composed by en echelon orderly alternation from tectonic kettles, morpostructural thresholds, morphostructural gorges and river valley morphostructures. This type of complex landforms is formed under the influence of the endogenous geodynamic processes. The complex morphostructural passages are specific regional morhounits in the high mountain regions of Bulgaria. They have different genesis and relative "passive" conduct trough the neighboring mountain relief building. The most important examples of this regional complex morphounit in Bulgaria are the Sub Balkan morphostructural zone (Tzankov, Stoyanov, [10]) in the Balkan Mountain chain belt, the Middle Struma, the Middle Mesta and the Strumeshnitsa River valley systems in South-West Bulgaria (Tzankov, Stoyanov, [10]) and the Middle Arda River valley system in the East Rhodope Mountain.

The bottoms of the tectonic kettles in the above mentioned complex morphostructural passages represent relics from the older alluvial plain of the post Early Pleistocene- orthoplain. The thresholds between the tectonic kettles are with the same genesis. They are more elevated and normally deeper eroded blocks (orthoplain fragments).

The principal difference between the complex morphostructural passage (morphostructural unit) and the compound "graben" (tectonic - structural units) is that the first one is obligatory landform. The graben can be a deformation effect in every part of the Earth's crust and its origin is not directly connected to the relief building.

Clarifying the regional morphotectonics environment necessary to conduct correlative analysis between finding of morphostructure and the results of previously conducted seismic, palaeogeographic investigation and various morphosculptural features of the surveyed lands.

\subsection{Internal Pattern of the Middle Struma Complex Morphostructural Passage}

The rock basement of the Middle Struma complex morphostructural passage is predominantly composed by Pre Cambrian metamorphic rocks, different Phanerozoic intrusive rocks and only in some parts - by Paleogene sediments (Rasmetanitsa mountain ridge in the area of the town of Dupnitsa) and volcanic rocks (Kozhuh mountain ridge, between the Struma River and Strumeshnitsa River) (Marinova et al., [11]). The passage bottom is covered by Late Miocene and Quaternary continental alluvial and proluvial deposits and contemporary river terraces (Tzankovet al., [7]).

The Middle Struma complex morphostructural passage is composed by consecutively submeridional linear orderly (from north to the south) Dupnitsa (Drenski Rid) morphostructural threshold, Dzherman morphostructural passage, Slatino morphostructural threshold, Mursalevo morphostructural passage, Kocherinovo morphostructural threshold, Riltsi kettle morphostructure, Byalo Pole morphostructural threshold, Blagoevgrad kettle morphostructure, Zheleznitsa morphostructural gorge, Simitli kettle morphostructure, Kresna morphostructural gorge, Sandanski morphostructural passage, Damyanitsa morphostructural threshold, Petrich kettle morphostructure 
and Rupel morphostructural gorge (Figure 2). The mentioned regional complex morphounits are limited by Bregalnitsa morphostructural zone to the west and the Rila-Pirin morphostrutural range to the east (Figure 2).

The internal mosaic (block) pattern of the mentioned compound morphounit is formed and controlled by the normal (high angular) and listric (low angular) faults of the regional fault net (Figure 2). The lateral passage borders matches approximately with the line of the contact between the mountain slope and the mountain foot - the zone with very dense disposition of the listric faults. The big parts of the passage bottom is covered by the horizontal or sub horizontal recent flood-plain benches, high flood-plain benches and relics from the different strong inclined (to the river-bed) over flood-plain river terraces (Figure 4). The terrace inclination grows up with the age of the bench. The uncovered by terraces bottom parts of the post Early Pleistocene denudation-accumulative surfaces are destructed by the listric and normal faults (Figure 3). The mentioned morphostructural peculiarities imparts an irregular character of the passage bottom (namely by the kettle morphostructures - Figure 3).

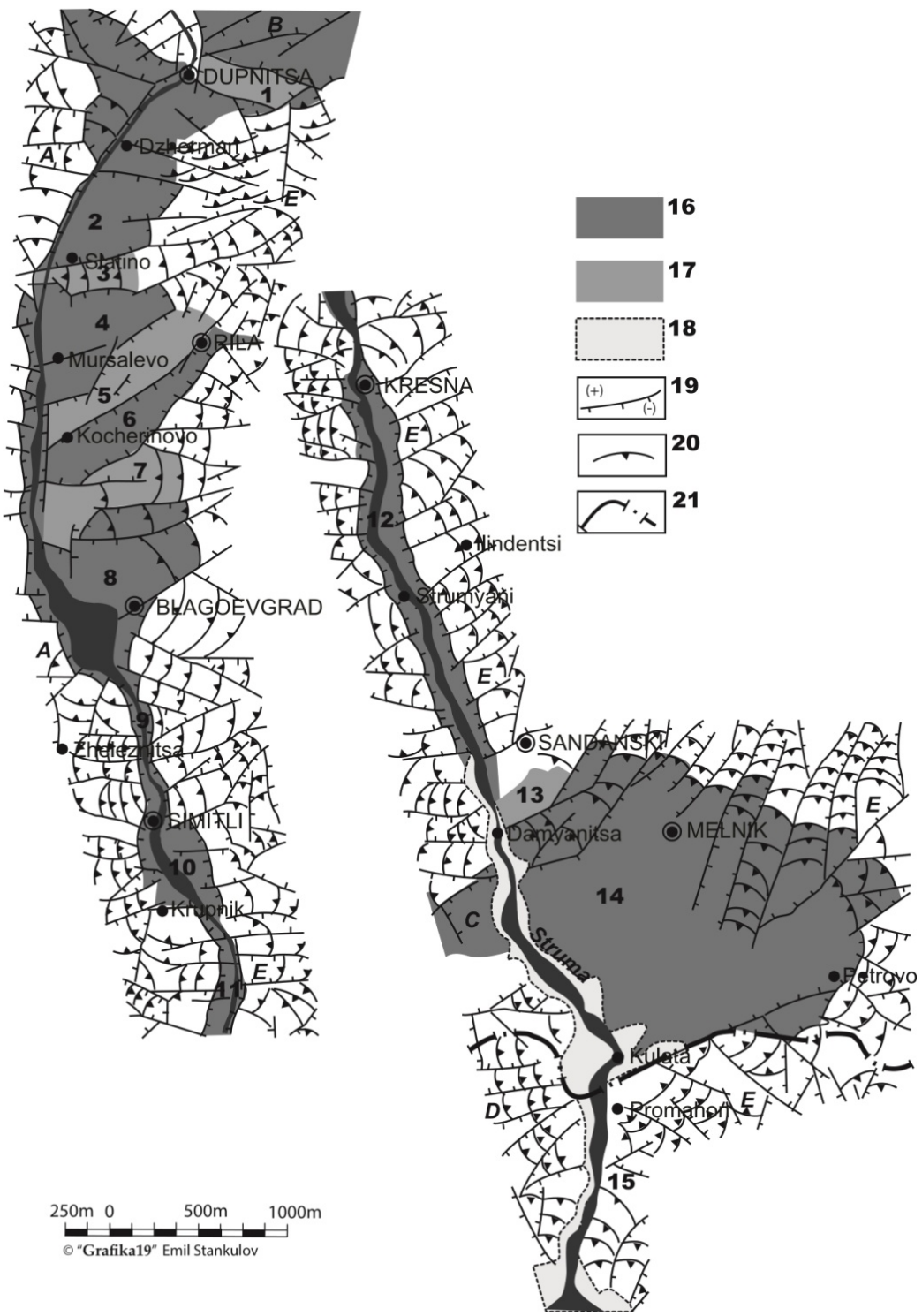

A - E - border regional morphounits: A - Bregalnitsa mophostructural zone, B - Kraishte-Sredna Gora morphostructural zone, C - Strumeshnitsa complex morphostructural passage, D- Belasitsa morphostructural zone, E- Rila-Pirin morphostructural range.

1 -15 - Middle Struma complex morphostructural passage: 1 - Dupnitsa morphostructural threshold, 2- Dzherman kettle morphostructure, 3 - Slatino morphostructural threshold, 4 - Mursalevo kettle morphostructure, 5 - Kocherinovo morphostructural threshold, 6- Riletska kettle morphostructure, 7 Byalo pole morphostructural threshold, 8 - Blagoevgrad kettle morphostructure, 9 - Zheleznitsa morphostructural gorge, 10 - Simitli kettle morphostructure, 11 - Kresna morphostructural gorge, 12 - Sandanski morphostructural passage, 13 - Damyanitsa morphostructural threshold, 14 Petrich kettle morphostructure, 15 -Rupel morphostructural gorge, 16 - rock basement of the Neogene and Quaternary alluvial and proluvial deposits, 17 - Neogene and Quaternary alluvial and proluvial deposits, 18 - spreading of the 100 meters river terrace, 19 - high angular normal fault, 20 - low angular listric fault, 21 - Bulgarian-Greece boundary.

Figure 2. Survey map of the internal pattern of the Middle Struma complex morphostructural passage 


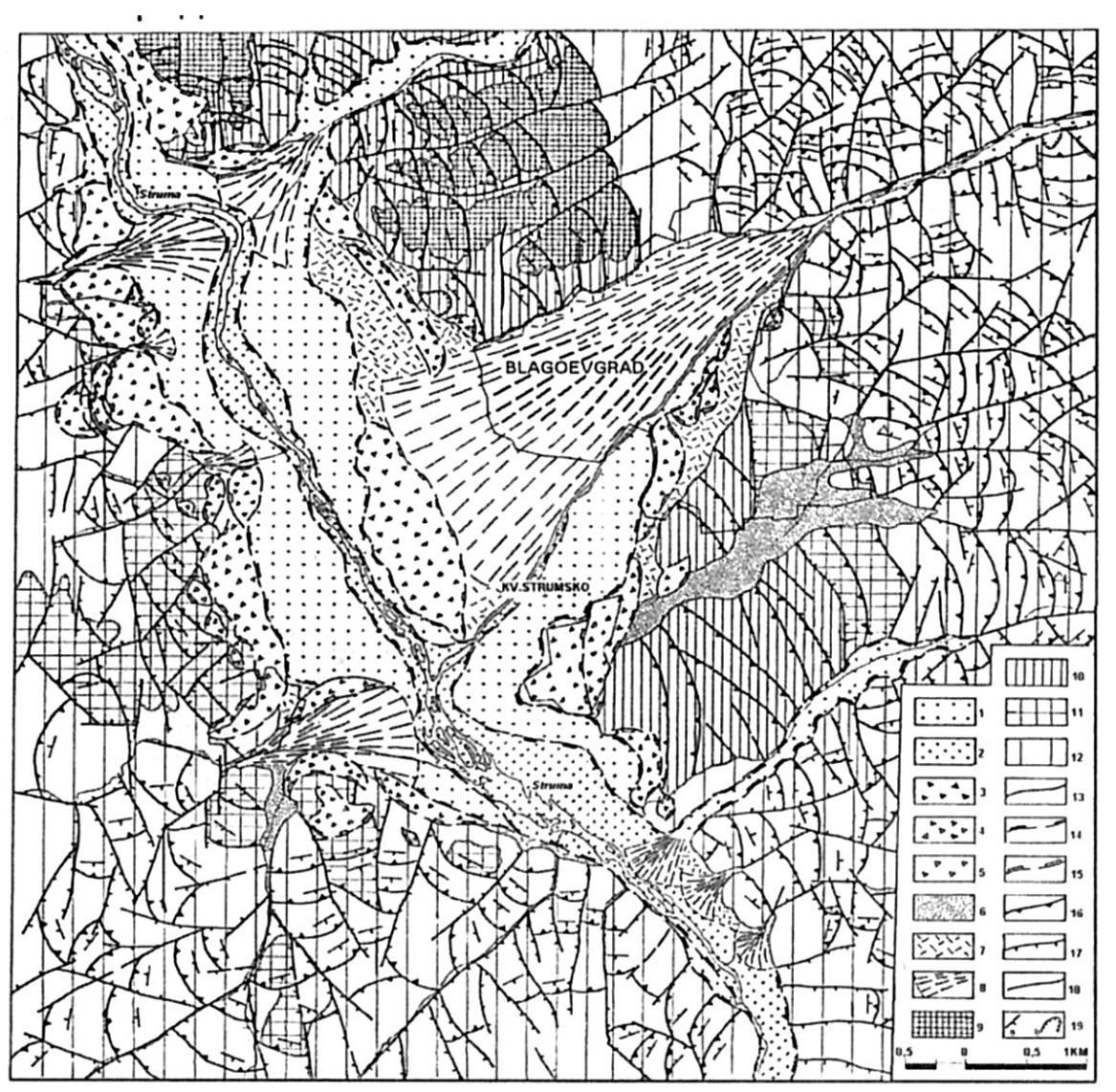

Figure 3. Geological-morphostructural map of the Blagoevgrad kettle morphostructure (after Tzankov et al., [7]) 1-flood-plain bench, 2-high flood-plain bench, 3-first over flood-plain river terrace, 4-second over flood-plain river terrace, 5-third over flood-plain river terrace, 6- alluvial deposits on the valley terraces, 7- delluvial deposits, 8- alluvial cone, 9- post Early Pleistocene denudation accumulative surface, 10- Dzherman Formation (Meotian), 11- Barakovo Formation (Pontian), pre Neogene rocks, 13- contact between the lithostratigraphic units, 14- rear (a) and frontal (b) boundary of the food-plain bench and high food plain bench, 15- rear (a) and frontal (b) boundary of the first, second and third flood-plain river terraces, 16- listric fault, 17- normal fault, 18- fault, 19- direction and dipping of the relics of the post Early Pleistocene denudation accumulative surface (a) and most important landslides (b).

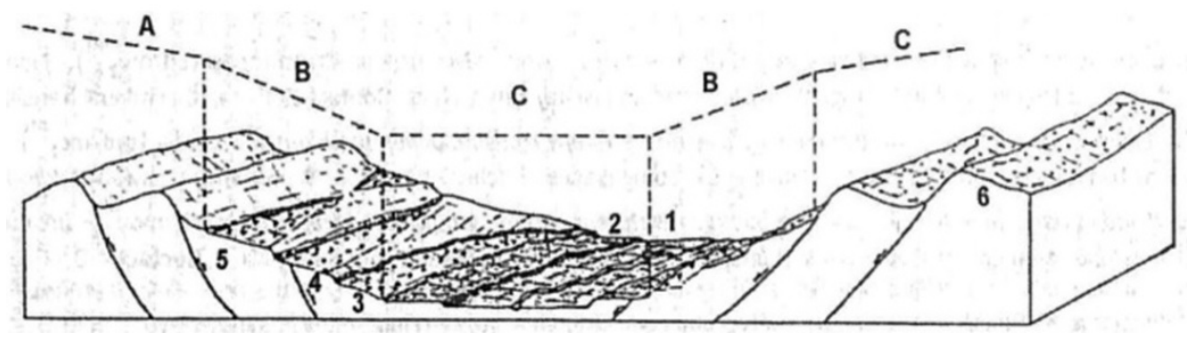

Figure 4. Generalized model of the spatial mutual relations between the flood-plain benches (1), over flood-plain benches (2), over flood-plain river terraces $(3,4,5)$ in the post Early Pleistocene denudation accumulative surfaces (6) (after Tzankov et al., [7])

The morphostructural thresholds are clear limited by normal or listric faults from the neighboring kettle morphostructure or morphostructural passage (Fig.2,3). Every threshold is connected to a transversal gorge. The threshold surface is relatively flat till subhorizontal. It is very oft cover by recent terrace deposits.

The morphostructural gorges are deep and cramped with relatively steep slopes. The gorge bottom is normal covered by recent terrace deposits.

\subsection{Seismic Activity}

In seismic terms the area of the Middle Struma complex morphostructural passage is part of the Aegean seismic zone of the Alpine-Himalayan seismic belt. In its length realize approximately $5-6 \%$ of earthquakes in the world. The Aegean region is one of the most active parts of the Mediterranean region in geodynamic sense. Seismicity here is a specific reflection of the processes in the Earth's crust and the uppermost part of the Earth's mantle. The 
concentration of seismic events around the Aegean Sea is much higher than in platforms and orogenic regions of Europe, North Africa and the Middle East.

The territory of the Middle Struma complex morphostructural passage is an element of Bulgarian continental microplate- a part from Neo Europe (Tzankov, Iliev, [12]). These lands are subject to ongoing intercontinental collision between the Eurasian and African continental macroplates. Significant part of created in these processes seismic energy is "released" in the area of the Middle Struma complex morphostructural passage. This explains the increased "secondary" seismic activity in the relevant parts from the morphostructural passage. The area is characterized by a moderate frequency of earthquakes. During the period 1965-2016 dominates the weak earthquakes. The strongest seismic event happened in 1985 on the southern edge of the Ograzhden Mountain and has a magnitude of 5.1 on the Richter scale.

Seismic intensity for the lands of the Middle Struma complex morphostructural passage is around IX ${ }^{\text {th }}$ grade on MKS-64 Intensity scale, only for the Ograzhden Mountain area of VIII $^{\text {th }}$ degree on MKS-64 Intensity scale. Higher seismic hazard should be expected in the central and southern parts of the morphostructural passage, mostly along the morphostructural gorges (Figure 5). In this sense, these lands represented one of the most dangerous in seismic sense zones not only in the Balkans, but also in whole continental Europe. In 1904, near the Krupnik Village emerged the strongest earthquake ever measured instrumentally in continental Europe, with magnitude 7.8 on the Richter scale. In the same year it was followed by a second earthquake with magnitude 7.2 on the Richter scale.

\section{Results and Discussion}

In the course of the study, the following main results were obtained:

1. The description and analysis of the construction of the Middle Struma complex morphostructural passage show that the latter is a successful model of the main features of the complex morphostructural passages in the eastern part of the Balkan Peninsula. These studies provide the opportunity for a comprehensive characterization of these complex composite morphostructures in view of their classification characteristics.

2. The earthquakes in the Middle Struma complex morphostructural passage area for the period 1965 2016 are concentrated in the Zheleznitsa, Kresna and Rupel morphostructural gorges. The other parts of the passage area are seismic passive. This circumstance show for the geodynamic activity in the contact zones between them.

3. The Middle Struma complex morphostructural passage was formed in the same time with the Late Pleistocene-Holocene dome-like morphosrtuctures of the fence morphostructural units. The investigated negative regional morphounit represent a part of the contemporary relief.

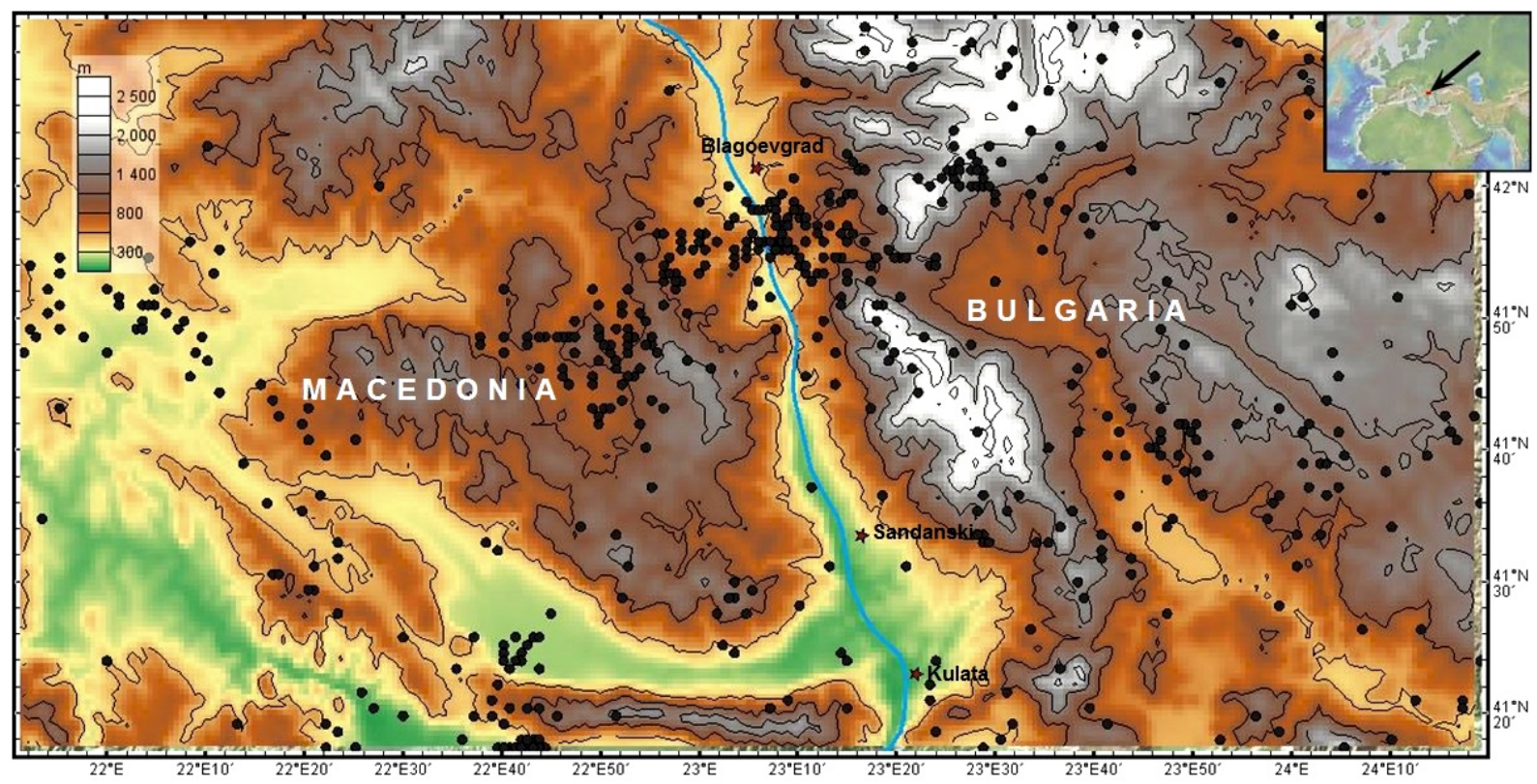

Figure 5. Earthquake epicenters in South-West Bulgaria for the period 1965-2016 (Mapping tool: GeoMapApp-http://www.geomapapp.org; Seismic data source: [13]) 
The conducted study characterizes the morphostructural type along the Middle Struma River Valley. The main differences with the current tectonic, not morphostructural features of the contemporary construction of the relief in Southwest Bulgaria are shown.

\section{Conclusions}

The complex morphostructural passages are everywhere widespread negative compound morphounits in the eastern part of the Balkan Peninsula. They represent post Early Pleistocene orthoplain fragments in its advanced destruction stage. Their regional sizes are constantly gradual reducing on the account of the enlargement of the areas with Late Pliocene and Holocene hill and mountain relief. The internal pattern of the complex morphostructural passages is very instructive about the character and details of the Earth's superficial geodynamic processes. It is showing for the stage and kind of the post Early Pleistocene orthoplain destruction in every parts of the different passage morphounits. Those regional morphostructural analysis contribute to the correct interpretation of the regional seismic events.

The Middle Struma complex morphostructural passage is one of the more representative negative compound morphounits in the eastern part of the Balkan Peninsula. It is the contemporary border land between the high elevated mountain massifs of Bregalnitsa morphostructural zone (to the west) and Rila-Pirin morphostructural range (to the east). This mophotectonic setting is controlled by first-rate endogenous geodynamic processes of the intercontinental collision between the Gondwana sinking north front down the Neo Europe in the eastern part of the Balkan Peninsula. The mentioned setting was predetermined the very advanced destruction stage of the Middle Struma post Early Pleistocene orthoplain fragment. This circumstance explains the character of the regional seismic activity.

\section{REFERENCES}

[1] Bakalov P. Litho-stratigraphic division of Blagoevgrad sediment system in Blagoevgrad Graben I. - Paleontol.,
Stratigr., Lithol., 9; 1978. 79-95 (in Bulgarian with an English abstract).

[2] Kojumdgieva E., Nikolov I., Nedjalkov P., Buzev A. Stratigraphy of the Neogene in Sandanski Graben. In: Geol. Balc., 12, 3; 1982. 69-71.

[3] Kojumdgieva E., Nedjalkov P., Cacev B. Neogene stratigraphy and development of Simitli Graben. In: Problems of Geology of South-West Bulgaria. Sofia, Bulgaria: Technika Press; 1984. 52-57.

[4] Nedjalkov P., Kojumdjieva E., Chermisin N., Nedialkov. Facial and paleogeography features of the Neogene sediments in Blagoevgrad graben. Rev. Bulg. Geol. Soc, 51, 1; 1990. 1-9 (in Bulgarian with an English summary)

[5] Nedjalkov P., Aleksiev G. Paleogeographic development of Struma Graben during Neogene. In: Problems of Geography, Sofia, Bulgaria, 1-2; 2004. 81-91

[6] Zagorchev I. Neotectonic development of Struma (Kraishtid) Lineament (Southwest Bulgaria and Northern Greece). In: Geol. Mag., Sofia, Bulgaria, 129, 2; 1991. $197-222$

[7] Tzankov Tz., Spassov N., Stoyanov Kr. Neogene-Quaternary paleogeography and geodynamics of the Middle Struma River. Blagoevgrad, Bulgaria: South-West University "NeofitRilski” Press; 2005 (in Bulgarian with an English summary)

[8] Tzankov Tz..Complex morphostructutral passages of the Rila-Rhodopean morphostructural zone (Bulgaria). Sofia, Bulgaria: International conference of the Institute of Geophysics, Geodesy and Geography by BAS, Proceedings; 2010. $192-197$

[9] Tzankov Tz..Morphostructural analysis. Sofia, Bulgaria: Publishing House "Grafika-19"; 2013 (in Bulgarian with English summary)

[10] Tzankov Tz., Stoyanov Kr. About geomorphological zoning of Bulgaria.vol.4.Stara Zagora, Bulgaria: International Conference "Union of scientists", Proceedings; 2003. 50-54 (in Bulgarian)

[11] Marinova R., Zagorchev I. Geology Map of Bulgaria on Scale 1:100 000. Blagoevgrad Map Sheet. Geological Institute of BAS, Sofia, Bulgaria; 1991.

[12] Tzankov Tz., Iliev R. Morphostructure of the Rhodopean mountain massif. Sofia, Bulgaria: Publishing House "Grafika-19"; 2015.

[13] Iris Earthquake Browser, Online available from http://www.iris.edu/hq/. 